DEVELOPMEN'T OF TETRAPLOIDY IN SAIMONIDS

T. REFSTIE

Agricultural University of Norway, As-NLH

At the Research Station for Salmonids, Sunndalsøra Unit, tetraploid rainbow trouts have been produced. This was obtained by keeping newly fertilized eggs for a short time in a solution containing cytochalasin B. The purpose of this work is to produce tetrapoid sterile fish by fertilizing normale eggs with sperm from tetraploid males.

GENETIC VARIATION IN FEED DIGESTIBILITY IN RAINBOW TROU'N

T. GJEDREM

Department of Animal Genetics and Breeding, Agricultural University of Norway, As-NLH

There was a significant variation between 'full sib families in digestibility and loss of weight during starvation. Phenotypic correlation between digestibility and loss of weights was not significant. The correlation between growth rate and body weight on one side and feed digestibility and loss of weight on the other side was significant.

EFFECT OF INBREEDING ON MORTALITY AND GROWTH IN RAINBOW TROUT

\title{
K. GUNNES
}

Department of Animal Genetics and Breeding, Agricultural University of Norway, As-NLH

Inbreeding experiments with rainbow trout have been carried out at the Research Station for Salmonids at Averøy and Sunndalsøra Unit. Three levels of inbreeding have been studied $(\mathrm{F}=0.25, \mathrm{~F}=0.375$ and $\mathrm{F}=0.50)$. The inbreeding depression for mortality in eggs before eying was zero, for eyed eggs 2.5 per cent, for alevins 1.9 per cent and for fry 3.2 per cent. No trend was found in depression with increasing level of inbreeding. The inbreeding depression for body weight of large rainbow trout was estimated to 4.9 per cent.

PRESERVATION OF RAINBOW TROUT (SALMO GAIRDNERI) SPERM AND EGGS

\section{J. STOSS, W. HOLZTZ}

\section{Institut $f$. Tierzucht und Haustiergenetik, 3400 Göttingen, Germany}

Undiluted semen was stored for 34 days at o ${ }^{\circ} \mathrm{C}$ under moisture-saturated oxygen without loss of fertilization capacity. Eggs were stored equally successfully for ro days under an atmosphere of moisture-saturated air.

Fertilization tates of more than 80 per cent of controls were obtained with frozen-thawed trout semen. It was found to be important that semen was frozen immediately after collection, that no time was allowed for equilibration before freezing and that fertilization of eggs was done as soon after thawing as possible. DMSO concentrations of $10-20$ per cent, pH values of $7-8, \mathrm{KCl}$ concentrations of $0-27 \mathrm{~m}$ mole were tolerated without detrimental effect in sperm cells. 